\title{
Formation of amides: one-pot condensation of carboxylic acids and amines mediated by $\mathrm{TiCl}_{4}$
}

\author{
Antonella Leggio*, Jessica Bagalà, Emilia Lucia Belsito, Alessandra Comandè, Marianna Greco \\ and Angelo Liguori
}

\begin{abstract}
A general procedure for the synthesis of amides via the direct condensation of carboxylic acids and amines in the presence of $\mathrm{TiCl}_{4}$ is reported. The amidation reaction was performed in pyridine at $85^{\circ} \mathrm{C}$ with a wide range of substrates providing the corresponding amide products in moderate to excellent yields and high purity. The reaction proceeds with low yields when both the carboxylic acid and the amine are sterically hindered. The process takes place with nearly complete preservation of the stereochemical integrity of chiral substrates.
\end{abstract}

Keywords: Amides, Titanium tetrachloride, Carboxylic acids, Amines, Condensation reaction

\section{Introduction}

Amide is a key functional group in organic chemistry for its widespread occurrence in peptide and non-peptide natural products, therapeutic small molecules, and new polymeric materials [1-4].

The most general way for obtaining amides involves the activation of the carboxylic function by means the conversion of carboxylic acids into the corresponding acid chlorides [5-8]. Subsequently this reactive derivative is coupled with the appropriate amine to yield the corresponding amide.

Alternatively, carboxylic acids, by the use of activating reagents, can be transformed into reactive acylating intermediates (acyl chlorides, anhydrides, activated esters) which directly react in situ with the suitable amines without their preliminary isolation and purification [9-12].

The use of coupling reagents is the only practicable way when the reagents useful for obtaining acid chlorides from carboxylic acids are not compatible with other chemical functions or protecting groups present on the substrate.

\footnotetext{
*Correspondence: antonella.leggio@unical.it; angelo.liguori@unical.it Dipartimento di Farmacia e Scienze della Salute e della Nutrizione, Università della Calabria Edificio Polifunzionale, 87036 Arcavacata, CS, Italy
}

The importance of amides has promoted the development of new protocols and reagents based on these approaches and alternative methods for amide bond formation [13-16].

The direct formation of amides by condensing nonactivated carboxylic acids and amines is extremely attractive because of its low environmental impact. Using metal-based catalysis in direct amide preparation, as an alternative to coupling reagents, has been reported [17-19].

The main synthetic catalysts employed for direct amidation are boronic acids and esters together with Lewis acid metal complexes.

Boron-based compounds are reported as catalysts promoting the condensation of carboxylic acids and amines in refluxing toluene $[20,21]$.

In addition amidation reaction protocols by using boronic acid and ester catalysts were also developed for the formation of dipeptide systems [22-24].

Under homogeneous conditions, the most used metal catalysts for direct coupling of carboxylic acids with amines are group IV metals.

In 1972 Werdehausen et al. [25] developed a catalytic procedure for the direct formation of amides starting from different long chain fatty acids and amines by using 
0.6-1 mol\% of metal catalysts based on $\mathrm{Ti}(\mathrm{IV}), \mathrm{Zr}(\mathrm{IV})$ and $\mathrm{Ta}(\mathrm{V})$, at $120-200^{\circ} \mathrm{C}$.

Later carboxyamides from benzoic acids and different amines were obtained by using stochiometric amounts of various Lewis acid catalysts in refluxing toluene [26].

$\mathrm{Ti}(\mathrm{OBu})_{4}$ was used in catalytic amounts for obtaining amides from several carboxylic acids and anilines in refluxing o-xylene with yields ranging from 38 to $98 \%$, electron donating groups on the aromatic ring of anilines provided higher conversions than electron withdrawing substituents $[27,28]$.

Different amides were synthesized using titanium(IV) isopropoxide as catalyst in $10-20 \mathrm{~mol} \%$ loading in THF [29]. Electronically and sterically demanding substrates provided their corresponding amides in moderate to good yields using a reaction temperature of $100{ }^{\circ} \mathrm{C}$. The hydrolytic decomposition of the catalyst caused a drastic lowering of the reaction yields when the reaction was performed in air.

The use of Zirconium(IV) catalysts for the direct amidation of carboxylic acids and amines was also reported [17]. $\mathrm{ZrCl}_{4}$ and $\mathrm{ZrCp}_{2} \mathrm{Cl}_{2}$ were particularly effective resulting in high conversions of the substrates after $4 \mathrm{~h}$ of reaction time at $110^{\circ} \mathrm{C}$ using a $5 \mathrm{~mol} \%$ catalyst.

Simultaneously, Adolfsson et al. developed a $\mathrm{ZrCl}_{4}$ catalysed amidation protocol at $70{ }^{\circ} \mathrm{C}$ in THF with molecular sieves as water scavengers [30,31]. Both aliphatic and aromatic carboxylic acids were converted in secondary and tertiary amides in $62-99 \%$ yield with $2-10 \mathrm{~mol} \%$ catalyst loading. Aromatic carboxylic acids required reaction temperatures of $100{ }^{\circ} \mathrm{C}$ and $10 \%$ catalyst loading in order to increase the yields after $24 \mathrm{~h}$ reaction time.

The sandwich complex bis(dicyclopentadienyl)hafnium dichloride $([\mathrm{Hf}(\mathrm{Cp}) 2 \mathrm{Cl} 2])$ was used as catalyst for direct amidation of nonactivated carboxylic acids at $26{ }^{\circ} \mathrm{C}$ [32]. The method provided different amides in a reaction time of $48 \mathrm{~h}$ and using a $10 \%$ catalyst loading. Some substrates were converted in the corresponding amides before this time.

In our research activity, in which titanium tetrachloride was employed, it was observed the oxophilic character of this transition metal towards carbonyl and hydroxyl groups [33-38].

On the base of these observations, we became interested in investigating the direct coupling of carboxylic acids and amines using $\mathrm{TiCl}_{4}$ as condensing agent.

Here, we report the successful $\mathrm{TiCl}_{4}$-mediated synthesis of secondary and tertiary amides starting from various carboxylic acid and amine precursors.

\section{Results and discussion}

Optimization of amidation reaction conditions was performed by choosing benzoic acid as model substrate.
The reaction was previously investigated under catalytic conditions. Benzoic acid $(1 \mathrm{mmol})$ and a catalytic amount of $\mathrm{TiCl}_{4}$ (30 mol\%) were treated with aniline $(1 \mathrm{mmol})$ in refluxing dry dichloromethane. During the addition of $\mathrm{TiCl}_{4}$ to the carboxylic acid, the production of hydrochloric acid was observed. After $12 \mathrm{~h}$ of reaction small amounts of amide (12\%) were obtained. Then the reaction was repeated for a longer reaction time $(24 \mathrm{~h})$. Also in this case the reaction did not proceed and the amide product was recovered with low yield (15\%). The poor outcome of the reaction prompted us to use a base to covert the carboxylic acid into the corresponding carboxylate. Pyridine was chosen as base to form the pyridinium carboxylate. It was not possible to use non-nucleophilic tertiary nitrogen bases such as triethylamine for the known reactivity of the trialkyl amines with $\mathrm{TiCl}_{4}[39,40]$. The reaction was designed in dichloromethane excluding ethereal solvents such as THF because, in the presence of $\mathrm{TiCl}_{4}, \mathrm{O}$-heterocycle ring opening reaction occurs [41, 42]. Therefore the amidation reaction was carried out in dichloromethane under reflux by treating benzoic acid $(1 \mathrm{mmol})$ with pyridine $(1 \mathrm{mmol})$ and $\mathrm{TiCl}_{4}(1.5 \mathrm{mmol})$, then aniline was added $(1 \mathrm{mmol})$. In the reaction mixture, during the adding of pyridine the formation of an insoluble salt, probably relating to the pyridinium salt, was observed. After a reaction time of $12 \mathrm{~h}$ benzanilide was recovered in $38 \%$ yield.

In the light of these results it was chosen to carry out the reaction in pyridine, which performs the function of solvent and base also by neutralizing the hydrochloric acid that develops during the reaction, using a higher temperature and an excess of $\mathrm{TiCl}_{4}$ to accelerate the reaction.

Benzoic acid $(1 \mathrm{mmol})$ was dissolved in pyridine $(10 \mathrm{~mL})$ in a screw capped vial. Then, to the resulting solution heated at $85{ }^{\circ} \mathrm{C}$, were added $\mathrm{TiCl}_{4}(3 \mathrm{mmol})$ and aniline $(1 \mathrm{mmol})$. After about $2 \mathrm{~h}$ reacting, the reaction was completed and the reaction mixture was acidified with $1 \mathrm{~N} \mathrm{HCl}$ aqueous solution and extracted with methylene chloride. The organic phase provided the N-phenylbenzamide in $98 \%$ yield and high purity as confirmed by GC/MS and NMR analyses.

Previously, $\mathrm{TiCl}_{4}$ was used in stoichiometric amounts to form carboxamides from carboxylic acids [18]. In this case the reaction was performed in THF or hexane as solvent and the nucleophilic amine was used in large excess to neutralize the hydrochloric acid produced during the reaction. The reported procedure is poorly applicable as the reaction times are very long ( $8 \mathrm{~h}-7$ days) also when heating is required.

Our result was particularly good and interesting, as the product was recovered pure in short times and in 
excellent yield without requiring the use of complex purification procedures.

Encouraged by the success of this preliminary study, the adopted procedure was applied for the preparation of a series of $\mathrm{N}$-phenylamides. Different alkyl and aryl carboxylic acids were tested under the developed reaction conditions using aniline, the amine component, as a constant (Scheme 1).
Aliphatic and aromatic carboxylic acids performed well, delivering the desired amides (1-7) in excellent yields (entry a-g, Table 1).

The molecular structure of the obtained amides was assigned by ${ }^{1} \mathrm{H}$ NMR, ${ }^{13} \mathrm{C}$ NMR and GC/MS analyses.

Additional experiments, that employed 2-fluoroaniline and 4-methylaniline as amine components, were carried out in order to investigate the electronic effect of

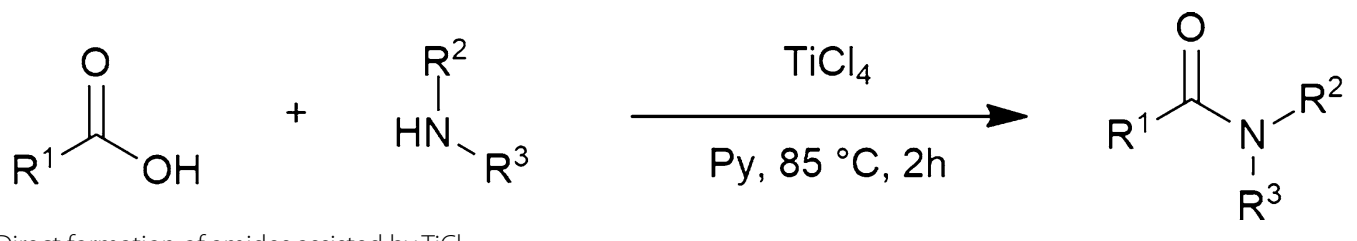

Scheme 1 Direct formation of amides assisted by $\mathrm{TiCl}_{4}$

Table 1 Synthesis of $\boldsymbol{N}$-phenylamides $1-7$

\begin{tabular}{|c|c|c|c|c|c|}
\hline Entry & $R^{1}$ & $\mathrm{R}^{2}$ & $R^{3}$ & Product & Yield (\%) \\
\hline a & $\mathrm{C}_{6} \mathrm{H}_{5}$ & $\mathrm{H}$ & $\mathrm{C}_{6} \mathrm{H}_{5}$ & 1 & 98 \\
\hline b & $4-\mathrm{NO}_{2}-\mathrm{C}_{6} \mathrm{H}_{4}$ & $\mathrm{H}$ & $\mathrm{C}_{6} \mathrm{H}_{5}$ & 2 & 98 \\
\hline c & $4-\mathrm{CH}_{3} \mathrm{O}-\mathrm{C}_{6} \mathrm{H}_{4}$ & $\mathrm{H}$ & $\mathrm{C}_{6} \mathrm{H}_{5}$ & 3 & 95 \\
\hline d & $4-\mathrm{Cl}-\mathrm{C}_{6} \mathrm{H}_{4}$ & $\mathrm{H}$ & $\mathrm{C}_{6} \mathrm{H}_{5}$ & 4 & 95 \\
\hline e & $\mathrm{C}_{6} \mathrm{H}_{5} \mathrm{CH}_{2}$ & $\mathrm{H}$ & $\mathrm{C}_{6} \mathrm{H}_{5}$ & 5 & 95 \\
\hline f & $\mathrm{C}_{6} \mathrm{H}_{5} \mathrm{CH}=\mathrm{CH}$ & $\mathrm{H}$ & $\mathrm{C}_{6} \mathrm{H}_{5}$ & 6 & 91 \\
\hline g & $\mathrm{C}_{15} \mathrm{H}_{31}$ & $\mathrm{H}$ & $\mathrm{C}_{6} \mathrm{H}_{5}$ & 7 & 88 \\
\hline
\end{tabular}


the substituent on the aniline nucleophilicity and consequently on the reaction course. The reactions went to completion in short times $(2 \mathrm{~h})$ and afforded the corresponding amides 8-9 in high yields (Scheme 1; Table 2).

The lower nucleophilicity of 2-fluoroaniline resulted in a lower yield of the corresponding amide (8) $(72 \%$, Table 2).

We explored also the reactivity of the more nucleophilic alkyl amines by choosing, as amine substrate, the propylamine. The standard protocol applied to the reaction of propylamine with aliphatic and aromatic carboxylic acids provided the corresponding amides 10-16 with yields higher than $90 \%$ (Scheme 1; Table 3 ).

Amide formation, by using the developed reaction protocol, was also studied with disubstituted amines that are often more difficult substrates since they exhibit a significant steric hindrance.

Diethylamine was chosen as a representative dialkyl amine for studying the influence of steric hindrance on the course of the reaction (Scheme 1; Table 4).

The desired tertiary $N, N$-diethylamides were obtained with satisfactory yields even though lower than secondary amides probably due to the steric hindrance of diethylamine (Table 4).

The results reported in Table 4 also suggested that, when diethyl amine is used as amine component, the reaction is affected by the electronic nature of the substituent on the aromatic ring of the benzoic acid (entry $\mathbf{r}$, entry $\mathbf{t}$ Table 4 ) which probably characterize the reactivity of the reaction intermediates.

In fact, the presence of chlorine and nitro group on the aromatic ring of carboxylic acids results in higher yields in amide $(\mathbf{1 8}, \mathbf{2 0}$, Table 4$)$ than substrates that have no substituents or have electron donor groups on the aromatic ring. $(17,19$, Table 4). This is consistent with the higher reactivity of the involved intermediates in the formation of $\mathbf{1 8}$ and $\mathbf{2 0 .}$

In many experiments in which benzoic acid was used, such as in the synthesis of $N, N$-diethylbenzamide (17), traces of benzoyl chloride were found in the crude product. This observation suggested that the acyl chloride could be the reaction intermediate.

The amidation reaction could proceed through the formation of an adduct (A) between the carboxylate ion, generated by the reaction of the carboxylic acid with pyridine, and $\mathrm{TiCl}_{4}$ (Scheme 2) as reported in literature with other metals [30]. The adduct $\mathbf{A}$ is characterized by the presence of a good leaving group that could lead to: (a) the direct formation of the amide; (b) the formation of the acyl pyridinium ion (B); (c) the formation of the acyl chloride $(C)$ (Scheme 2). $\mathbf{B}$ and $\mathbf{C}$ could act as additional reaction intermediates for the formation of the amide.

The reaction of the sterically hindered pivalic acid with diethylamine resulted with very low conversions and provided, after $2 \mathrm{~h}$, the corresponding amide $\mathbf{2 6}$ in $9 \%$ yield. (entry $\mathbf{z}$, Table 5). When the reaction was performed by treating pivalic acid with aniline and propylamine (entry $\mathbf{x}-\mathbf{y}$, Table 5 ), the amides $\mathbf{2 4}$ and 25 were recovered respectively with 90 and $75 \%$ yield (Table 5) demonstrating that the steric effect of the carboxylic acid alone has minor impact on the reaction course.

In these reactions, steric effects play a key role when both amine and carboxylic acid are sterically hindered.

We also explored the stereochemical outcome of the adopted procedure by synthesizing a couple of anilide enantiomers 27 and 28 starting from $(S)$-2-(N-tertbutoxycarbonylamino)propanoic acid ( $N$-Boc-L-Alanine) and $(R)-2-(N$-tert-butoxycarbonylamino)propanoic acid (N-Boc-D-Alanine) as acid substrates respectively (Scheme 3). Gratifyingly, we were able to synthesize the two enantiomers with high enantioselectivity.

$N$-Boc-L-alanine and N-Boc-D-alanine reacted with aniline in the presence of $\mathrm{TiCl}_{4}$ affording the corresponding amides $\mathbf{2 7}$ and $\mathbf{2 8}$ respectively in 88 and $87 \%$ \% yield (Scheme 3).

Table 2 Synthesis of substituted anilides 8-9

\begin{tabular}{|c|c|c|c|c|c|}
\hline Entry & $R^{1}$ & $R^{2}$ & $\mathrm{R}^{3}$ & Product & Yield (\%) \\
\hline $\mathbf{h}$ & $\mathrm{C}_{6} \mathrm{H}_{5} \mathrm{CH}_{2}$ & $\mathrm{H}$ & $2-\mathrm{F}-\mathrm{C}_{6} \mathrm{H}_{4}$ & 8 & 72 \\
\hline $\mathbf{i}$ & $\mathrm{C}_{6} \mathrm{H}_{5} \mathrm{CH}_{2}$ & $\mathrm{H}$ & $4-\mathrm{CH}_{3}-\mathrm{C}_{6} \mathrm{H}_{4}$ & 9 & 98 \\
\hline
\end{tabular}


Table 3 Synthesis of $\mathbf{N}$-propylamides 10-16

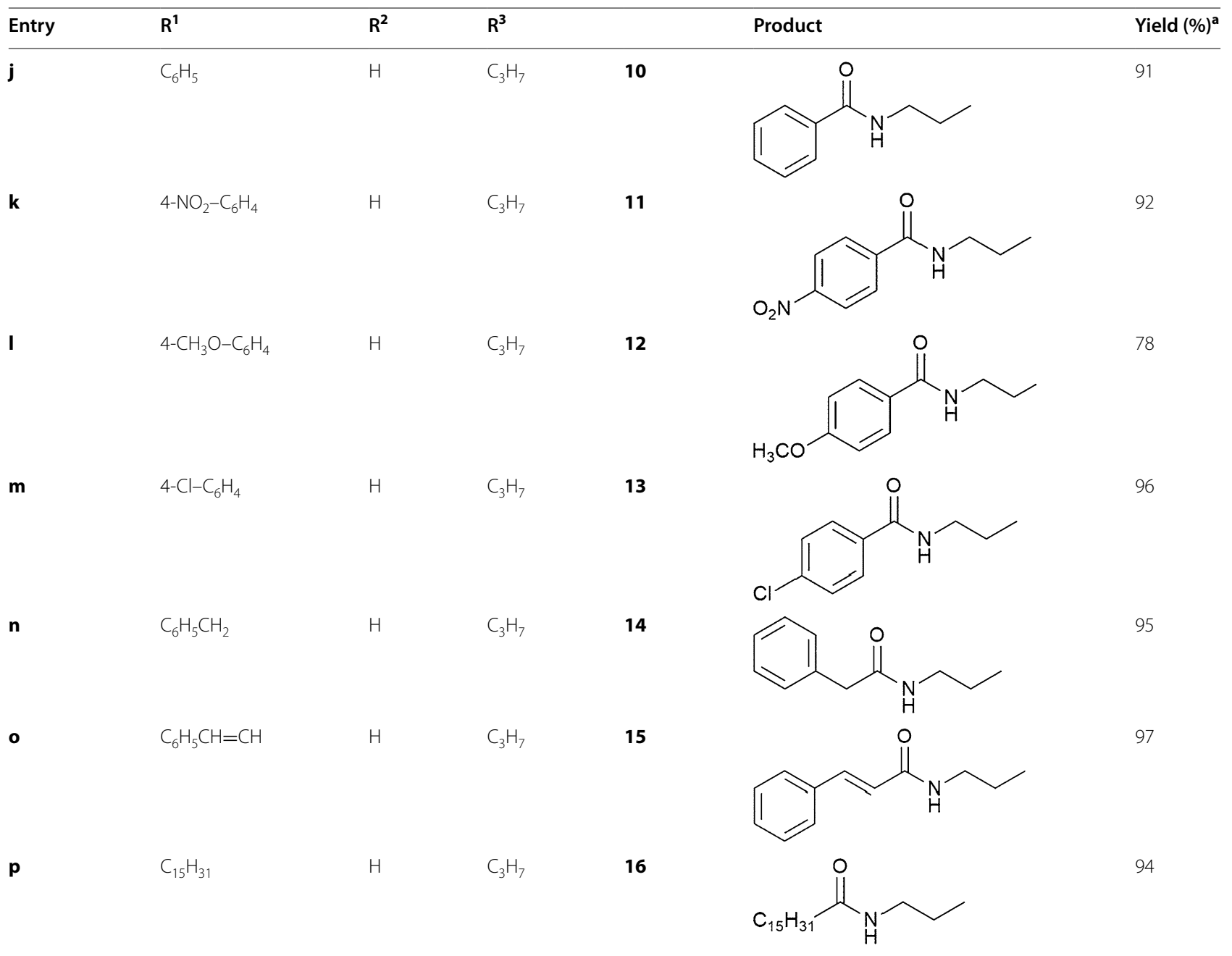

a Isolated yields

This result demonstrates that this reaction works well also with carboxylic acids bearing acid-labile protecting groups.

The enantiomeric purity of each crude product 27 and 28 was assessed by analyzing them by chiral GC/MS and comparing the resulting chromatograms with that of a suitably prepared mixture (approx. 1:1) of the two enantiomers (Fig. 1). The two enantiomers of the mixture, after finding the optimal conditions for achieving good selectivity, were resolved by chiral GC/MS: two peaks with retention times of 223.46 and 224.55 min corresponding to $\mathbf{2 8}$ and $\mathbf{2 7}$ respectively appeared in the chromatogram (Fig. 1b).

The comparison of the chromatograms of the single crude enantiomers $\mathbf{2 7}$ and $\mathbf{2 8}$ (Fig. 1a, c) with the mixture and the integration gave the data for the enantiomeric excess (ee) calculation, which was $95 \%$ for the D-isomer and $93 \%$ for the L-isomer. The calculated enantiomeric excess was for both enantiomers satisfactory.

\section{Conclusion}

A general approach to generate amides has been established using $\mathrm{TiCl}_{4}$-induced direct condensation of carboxylic acids with amines.

Our procedure was successfully applied to a broad spectrum of readily available carboxylic acids and amines affording, in short times and after a simple work up, the corresponding amides in high purity and yields.

By using N-Boc-L-alanine and its enantiomer $N$-BocD-alanine as chiral carboxylic acids, and aniline as amine component, highly enantiomerically enriched anilides were synthesized, demonstrating that the developed procedure does not generate any significant loss of the optical integrity of the precursors. 
Table 4 Synthesis of $\mathbf{N}, \mathbf{N}$-diethylamides 17-23

\begin{tabular}{|c|c|c|c|c|c|c|}
\hline Entry & $\mathrm{R}^{1}$ & $R^{2}$ & $R^{3}$ & & Product & Yield (\%) \\
\hline $\mathbf{q}$ & $\mathrm{C}_{6} \mathrm{H}_{5}$ & $\mathrm{C}_{2} \mathrm{H}_{5}$ & $\mathrm{C}_{2} \mathrm{H}_{5}$ & 17 & & 64 \\
\hline $\mathbf{r}$ & $4-\mathrm{NO}_{2}-\mathrm{C}_{6} \mathrm{H}_{4}$ & $\mathrm{C}_{2} \mathrm{H}_{5}$ & $\mathrm{C}_{2} \mathrm{H}_{5}$ & 18 & & 80 \\
\hline s & $4-\mathrm{CH}_{3} \mathrm{O}-\mathrm{C}_{6} \mathrm{H}_{4}$ & $\mathrm{C}_{2} \mathrm{H}_{5}$ & $\mathrm{C}_{2} \mathrm{H}_{5}$ & 19 & & 56 \\
\hline $\mathbf{t}$ & $4-\mathrm{Cl}-\mathrm{C}_{6} \mathrm{H}_{4}$ & $\mathrm{C}_{2} \mathrm{H}_{5}$ & $\mathrm{C}_{2} \mathrm{H}_{5}$ & 20 & & 77 \\
\hline $\mathbf{u}$ & $\mathrm{C}_{6} \mathrm{H}_{5} \mathrm{CH}_{2}$ & $\mathrm{C}_{2} \mathrm{H}_{5}$ & $\mathrm{C}_{2} \mathrm{H}_{5}$ & 21 & & 85 \\
\hline $\mathbf{v}$ & $\mathrm{C}_{6} \mathrm{H}_{5} \mathrm{CH}=\mathrm{CH}$ & $\mathrm{C}_{2} \mathrm{H}_{5}$ & $\mathrm{C}_{2} \mathrm{H}_{5}$ & 22 & & 87 \\
\hline $\mathbf{w}$ & $\mathrm{C}_{15} \mathrm{H}_{31}$ & $\mathrm{C}_{2} \mathrm{H}_{5}$ & $\mathrm{C}_{2} \mathrm{H}_{5}$ & 23 & & 91 \\
\hline
\end{tabular}

${ }^{a}$ Isolated yields

The current investigation showed also that this approach works well also with carboxylic acids bearing acid-sensitive groups.

\section{Experimental}

\section{General experimental details}

All reagents were purchased commercially without further purification. Solvents were purified according to well-known laboratory methods and freshly distilled prior to use. Reaction were carried out in a tightly sealed screw-capped vial. Reactions were magnetically stirred and monitored by thin layer chromatography using Merck-Kieselgel 60 F254 plates. ${ }^{1} \mathrm{H}$ and ${ }^{13} \mathrm{C}$ NMR spectra were recorded on a Bruker Avance 300 instrument at $300 \mathrm{MHz}$ and $75 \mathrm{MHz}$, respectively. Spectroscopic analysis was performed at $293 \mathrm{~K}$ on diluted solutions of each compound by using $\mathrm{CDCl}_{3}$ and DMSO- $\mathrm{d}_{6}$ as the solvents. Chemical shifts $(\delta)$ are reported in ppm. Coupling constants $(\mathrm{J})$ are reported in Hertz $(\mathrm{Hz})$ (Additional file 1).
GC-MS analyses were performed with a DB-35MS (20 m $\times 0.18 \mathrm{~mm}$, 35\% Phenyl 65\% dimethylpolysiloxane) capillary column. The mass detector was operated in the electron impact ionization mode (EI/MS) with an electron energy of $70 \mathrm{eV}$. The injection port was heated to $250{ }^{\circ} \mathrm{C}$. The oven temperature program was initially set at $70{ }^{\circ} \mathrm{C}$ with a hold of $2 \mathrm{~min}$ and ramped to $280{ }^{\circ} \mathrm{C}$ at $20^{\circ} \mathrm{C} / \mathrm{min}$ with a hold of $10 \mathrm{~min}$. Chiral GC-MS analyses of enantiomeric compounds 27-28 were performed by using a $25 \mathrm{~m} \times 0.25 \mathrm{~mm}$, Diethyl tertbutyldimethylisilyl$\beta$-cyclodextrine chiral capillary column. The injection port was heated to $250{ }^{\circ} \mathrm{C}$. The oven temperature program was initially set at $50{ }^{\circ} \mathrm{C}$, with a hold of $2 \mathrm{~min}$, ramped to $250{ }^{\circ} \mathrm{C}$ at $0.5^{\circ} \mathrm{C} / \mathrm{min}$ with a hold of $5 \mathrm{~min}$.

\section{General procedure for the synthesis of amides 1-28}

$\mathrm{TiCl}_{4}(3 \mathrm{mmol})$ and the amine $(1 \mathrm{mmol})$ were added to a solution of carboxylic acid $(1 \mathrm{mmol})$ in pyridine $(10 \mathrm{~mL})$. The tightly sealed screw-capped vial containing the 
<smiles></smiles><smiles>[R]C(=O)Cl</smiles>

C

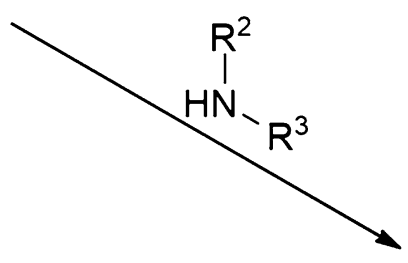<smiles>[R]C(=O)[O-]</smiles>

A<smiles>Cc1ccccc1</smiles>

$\mathrm{R}^{1}$
B<smiles>[R]C(=O)[n+]1ccccc1</smiles>

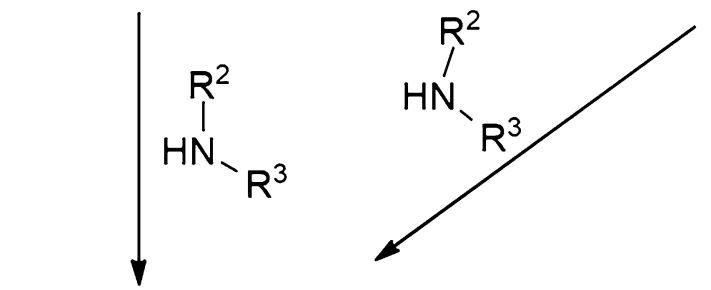<smiles>[R]C(=O)N([R])[R]</smiles>

Scheme 2 Proposed mechanism for the $\mathrm{TiCl}_{4}$ assisted direct amidation

Table 5 Synthesis of pivalic acid amides 24-26

\begin{tabular}{llllll}
\hline Entry & $\mathbf{R}^{\mathbf{1}}$ & $\mathbf{R}^{\mathbf{2}}$ & $\mathbf{R}^{\mathbf{3}}$ & Product $^{\text {Yield (\%) }}$ \\
\hline $\mathbf{x}$ & $\left(\mathrm{CH}_{3}\right)_{3} \mathrm{C}$ & $\mathrm{H}$ & $\mathrm{C}_{6} \mathrm{H}_{5}$ & $\mathbf{2 4}$ & $\mathbf{2 5}$ \\
$\mathbf{z}$ & $\left(\mathrm{CH}_{3}\right)_{3} \mathrm{C}$ & $\mathrm{H}$ & $\mathrm{C}_{3} \mathrm{H}_{7}$ & $\mathbf{2 6}$ &
\end{tabular}

a Isolated yields

reaction mixture was then heated at $85{ }^{\circ} \mathrm{C}$. After magnetic stirring for about $2 \mathrm{~h}$, TLC analysis (chloroform/ methanol 90:10 v/v) of the reaction mixture showed complete conversion of the carboxylic acid precursor. The reaction mixture was then cooled, and after removing pyridine by co-evaporation with toluene, was treated with an aqueous $1 \mathrm{~N} \mathrm{HCl}$ solution $(10 \mathrm{~mL})$ and extracted with methylene chloride $(3 \times 10 \mathrm{~mL})$. The combined organic extracts were washed with a saturated aqueous solution of sodium bicarbonate $(3 \times 10 \mathrm{~mL})$, dried $\left(\mathrm{Na}_{2} \mathrm{SO}_{4}\right)$, and evaporated to dryness under reduced pressure to afford 
<smiles>CC(NC(=O)OC(C)(C)C)C(=O)O</smiles>

Scheme 3 Direct formation of enantiomeric amides $\mathbf{2 7 - 2 8}$ assisted by $\mathrm{TiCl}_{4}$<smiles>C[C@H](NC(=O)OC(C)(C)C)C(=O)Nc1ccccc1</smiles>

27 (L); 28 (D) the corresponding amides $\mathbf{1 - 2 8}$ with yields ranging from 56 to $98 \%$.

\section{N-phenylbenzamide (1)}

Solid (98\%); $\mathrm{mp}=163-165{ }^{\circ} \mathrm{C} ; \mathrm{Rf}=0.70 ;{ }^{1} \mathrm{H}$ NMR $\left(300 \mathrm{MHz}, \mathrm{DMSO}-\mathrm{d}_{6}\right) \delta: 10.23(\mathrm{~s}, 1 \mathrm{H}), 7.99-7.95(\mathrm{~m}$, $2 \mathrm{H}), 7.81-7.78(\mathrm{~m}, 2 \mathrm{H}), 7.56-7.52(\mathrm{~m}, 3 \mathrm{H}), 7.38-7.32(\mathrm{~m}$, $2 \mathrm{H}), 7.12-7.07(\mathrm{~m}, 1 \mathrm{H}) ;{ }^{13} \mathrm{C}-\mathrm{NMR}\left(75 \mathrm{MHz}\right.$, DMSO-d $\left.\mathrm{d}_{6}\right)$ $\delta: 166.0,139.7,135.5,131.9,129.0,128.8,128.1,124.1$, 120.9; GC/MS (EI) $m / z$ (\% rel.): 197 [M $\left.\mathrm{M}^{+\cdot}\right]$ (46), 105 (100), 77 (46); 65 (4), 51 (9).

\section{4-nitro-N-phenylbenzamide (2)}

Solid (98\%); $\mathrm{mp}=218-220{ }^{\circ} \mathrm{C}$; $\mathrm{Rf}=0.65 ;{ }^{1} \mathrm{H}$ NMR $\left(300 \mathrm{MHz}, \mathrm{DMSO}-\mathrm{d}_{6}\right) \delta: 10.53(\mathrm{~s}, 1 \mathrm{H}), 8.35(\mathrm{~d}, \mathrm{~J}=9.0 \mathrm{~Hz}$, $2 \mathrm{H}), 8.18(\mathrm{~d}, \mathrm{~J}=9.0 \mathrm{~Hz}, 2 \mathrm{H}), 7.78(\mathrm{~d}, \mathrm{~J}=7.5 \mathrm{~Hz}, 2 \mathrm{H})$, 7.46-7.27 (m, 2H), $7.13(\mathrm{t}, \mathrm{J}=7.4 \mathrm{~Hz}, 1 \mathrm{H}) ;{ }^{13} \mathrm{C}-\mathrm{NMR}$ (75 MHz, DMSO-d ${ }_{6}$ ) $\delta: 164.3,149.6,141.1,139.2,129.7$, 129.1, 124.6, 124.0, 121.0; GC/MS (EI) $m / z$ (\% rel.): 242 $\left[\mathrm{M}^{+\cdot}\right]$ (75), 150 (100), 120 (21), 104 (32), 92 (20), 76 (25).

\section{4-methoxy-N-phenylbenzamide (3)}

Solid (95\%); $\mathrm{mp}=177-179{ }^{\circ} \mathrm{C} ; \mathrm{Rf}=0.69 ;{ }^{1} \mathrm{H}$ NMR (300 MHz, DMSO-d $)$ $) \delta: 10.06(\mathrm{~s}, 1 \mathrm{H}), 7.99-7.88(\mathrm{~m}, 2 \mathrm{H})$, 7.80-7.74 (m, 2H), 7.39-7.24 (m, 2H), 7.13-6.99 (m, 3H), $3.83(\mathrm{~s}, 3 \mathrm{H}) ;{ }^{13} \mathrm{C}-\mathrm{NMR}(75 \mathrm{MHz}$, DMSO-d 6 ) $\delta: 165.4$, 162.4, 139.9, 130.0, 129.0, 127.5, 123.9, 120.9, 114.1, 55.9; GC/MS (EI) $m / z$ (\% rel.): $227\left[\mathrm{M}^{+}\right]$(21), 135 (100), 107 (6), 92 (11), 77(12).

\section{4-chloro-N-phenylbenzamide (4)}

Solid (95\%); $\mathrm{mp}=205-207{ }^{\circ} \mathrm{C} ; \mathrm{Rf}=0.78 ;{ }^{1} \mathrm{H}$ NMR $\left(300 \mathrm{MHz}\right.$, DMSO- $\left.\mathrm{d}_{6}\right) \delta: 10.28(\mathrm{~s}, 1 \mathrm{H}), 8.06-7.88(\mathrm{~m}$, $2 \mathrm{H}), 7.82-7.71(\mathrm{~m}, 2 \mathrm{H}), 7.64-7.53 \mathrm{~m}, 2 \mathrm{H}), 7.40-7.28(\mathrm{~m}$, $2 \mathrm{H}), 7.10(\mathrm{t}, \mathrm{J}=7.4 \mathrm{~Hz}, 1 \mathrm{H}) ;{ }^{13} \mathrm{C}-\mathrm{NMR}(75 \mathrm{MHz}$, DMSO$\left.\mathrm{d}_{6}\right) \delta: 164.9,139.5,136.9,134.1,130.1,129.1,128.9,124.3$, 120.9; GC/MS (EI) $m / z$ (\% rel.): $231\left[\mathrm{M}^{+\cdot}\right]$ (31), 139 (100), 111 (31), 75 (12).

\section{N,2-diphenylacetamide (5)}

Solid (95\%); mp $=105-107{ }^{\circ} \mathrm{C} ; \mathrm{Rf}=0.73 ;{ }^{1} \mathrm{H}$ NMR $\left(300 \mathrm{MHz}, \mathrm{CDCl}_{3}\right) \delta: 7.63$ ( $\left.\mathrm{s}_{\text {broad }}, 1 \mathrm{H}\right), 7.49-7.42(\mathrm{~m}, 2 \mathrm{H})$,
7.39-7.21 (m, 7H), $7.09(\mathrm{t}, \mathrm{J}=7.4 \mathrm{~Hz}, 1 \mathrm{H}), 3.70(\mathrm{~s}, 2 \mathrm{H})$; ${ }^{13} \mathrm{C}$-NMR $\left(75 \mathrm{MHz}, \mathrm{CDCl}_{3}\right) \delta: 169.4,137.8,134.6,129.5$, 129.1, 128.9, 127.6, 124.4, 120.0, 44.7; GC/MS (EI) $\mathrm{m} / z$ (\% rel.): $211\left[\mathrm{M}^{+\cdot}\right]$ (49), 119 (11), 91(68), 93 (100), 77 (11), 65 (21).

\section{N-phenylcinnamamide (6)}

Solid (91\%); $\mathrm{mp}=155-157{ }^{\circ} \mathrm{C} ; \mathrm{Rf}=0.72 ;{ }^{1} \mathrm{H}$ NMR $\left(300 \mathrm{MHz}, \mathrm{CDCl}_{3}\right) \delta: 8.09(\mathrm{~s}, 1 \mathrm{H}), 7.75(\mathrm{~d}, \mathrm{~J}=15.6 \mathrm{~Hz}$, $1 \mathrm{H}), 7.69-7.59(\mathrm{~m}, 2 \mathrm{H}), 7.52-7.39(\mathrm{~m}, 2 \mathrm{H}), 7.38-7.23(\mathrm{~m}$, $5 \mathrm{H}), 7.12(\mathrm{t}, \mathrm{J}=7.4 \mathrm{~Hz}, 1 \mathrm{H}), 6.66(\mathrm{~d}, \mathrm{~J}=15.6 \mathrm{~Hz}, 1 \mathrm{H})$; ${ }^{13} \mathrm{C}-\mathrm{NMR}\left(75 \mathrm{MHz}, \mathrm{CDCl}_{3}\right.$ ) $\delta: 164.7,142.2,138.2,134.6$, 129.9, 129.1, 128.8, 128.0, 124.5, 121.2, 120.4; GC/MS (EI) $m / z$ (\% rel.): $223\left[\mathrm{M}^{+}\right]$(25), 131 (100) 103 (36), 93 (19), 77 (24).

\section{N-phenylpalmitamide (7)}

Solid (88\%), $\mathrm{mp}=88-90{ }^{\circ} \mathrm{C}$; Rf $=0.81 ;{ }^{1} \mathrm{H}$ NMR $\left(300 \mathrm{MHz}, \mathrm{CDCl}_{3}\right) \delta: 7.53(\mathrm{~d}, \mathrm{~J}=8.3 \mathrm{~Hz}, 2 \mathrm{H}), 7.40(\mathrm{~s}$, $1 \mathrm{H}), 7.36-7.22(\mathrm{~m}, 2 \mathrm{H}), 7.11(\mathrm{~m}, 1 \mathrm{H}), 2.42-2.29(\mathrm{~m}$, $2 \mathrm{H}), 1.80-1.60(\mathrm{~m}, 2 \mathrm{H}), 1.41-1.13(\mathrm{~m}, 24 \mathrm{H}),, 0.89(\mathrm{t}$, $\mathrm{J}=6.7 \mathrm{~Hz}, 3 \mathrm{H}) ;{ }^{13} \mathrm{C}-\mathrm{NMR}\left(75 \mathrm{MHz}, \mathrm{CDCl}_{3}\right) \delta: 171.7$, 137.9, 129.0, 124.2, 119.8, 37.8, 31.9, 29.7, 29.6, 29.5, 29.4, 29.3, 25.7, 22.7, 14.2; GC/MS (EI) $m / z$ (\% rel.): $331\left[\mathrm{M}^{+\cdot}\right]$ (2), 135 (19), 93 (100), 77 (2).

\section{$\mathrm{N}$-(2-fluorophenyl)-2-phenylacetamide (8)}

Solid (72\%), $\mathrm{mp}=100-102{ }^{\circ} \mathrm{C}$; Rf $=0.85 ;{ }^{1} \mathrm{H}$ NMR $\left(300 \mathrm{MHz}, \mathrm{CDCl}_{3}\right) \delta: 8.29(\mathrm{t}, \mathrm{J}=8.0 \mathrm{~Hz}, 1 \mathrm{H}), 7.53-7.30$ (m, 6H), 7.16-7.06 (m, 1H), 7.06-6.95 (m, 2H), 3.78 (s, 2H); ${ }^{13} \mathrm{C}-\mathrm{NMR}\left(75 \mathrm{MHz}, \mathrm{CDCl}_{3}\right) \delta: 169.2,152,1$ $(\mathrm{d}, \mathrm{J}=242.5 \mathrm{~Hz}), 134.1,129.5,129.3,127.8,126.2(\mathrm{~d}$, $\mathrm{J}=10.3 \mathrm{~Hz}), 124.54(\mathrm{~d}, \mathrm{~J}=3.8 \mathrm{~Hz}), 124.51(\mathrm{~d}, \mathrm{~J}=7.6 \mathrm{~Hz})$, 121.7, 114.7 (d, J = 19.4 Hz), 44.8; GC/MS (EI) $\mathrm{m} / z$ (\% rel.): $229\left[\mathrm{M}^{+\cdot}\right]$ (25), 118 (24), 111 (100), 91 (76), 65 (13).

\section{2-phenyl-N-(p-tolyl)acetamide (9)}

Solid (98\%), $\mathrm{mp}=108-110{ }^{\circ} \mathrm{C} ; \mathrm{Rf}=0.73 ;{ }^{1} \mathrm{H}$ NMR $\left(300 \mathrm{MHz}, \mathrm{CDCl}_{3}\right)$ 8: $7.52\left(\mathrm{~s}_{\text {broad }}, 1 \mathrm{H}\right), 7.43-7.28(\mathrm{~m}$, $7 \mathrm{H}), 7.07$ (d, J = 8.3 Hz, 2H), 3.69 (s, 2H), 2.29 (s, 3H); ${ }^{13} \mathrm{C}-\mathrm{NMR}\left(75 \mathrm{MHz}, \mathrm{CDCl}_{3}\right) \delta: 169.3,135.2,134.7,134.0$, 129.5, 129.4, 129.1, 127.5, 120.1, 44.6, 20.9; GC/MS (EI) 


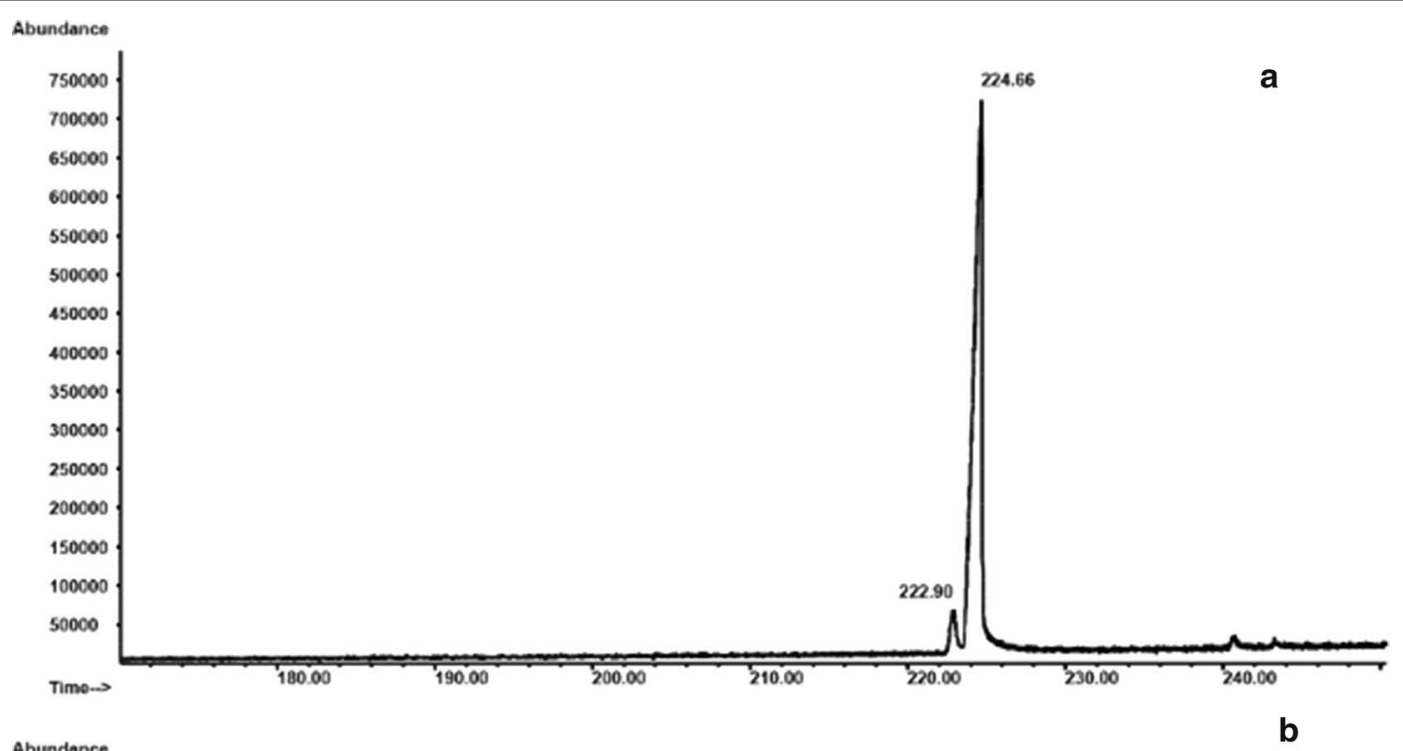

Abundance

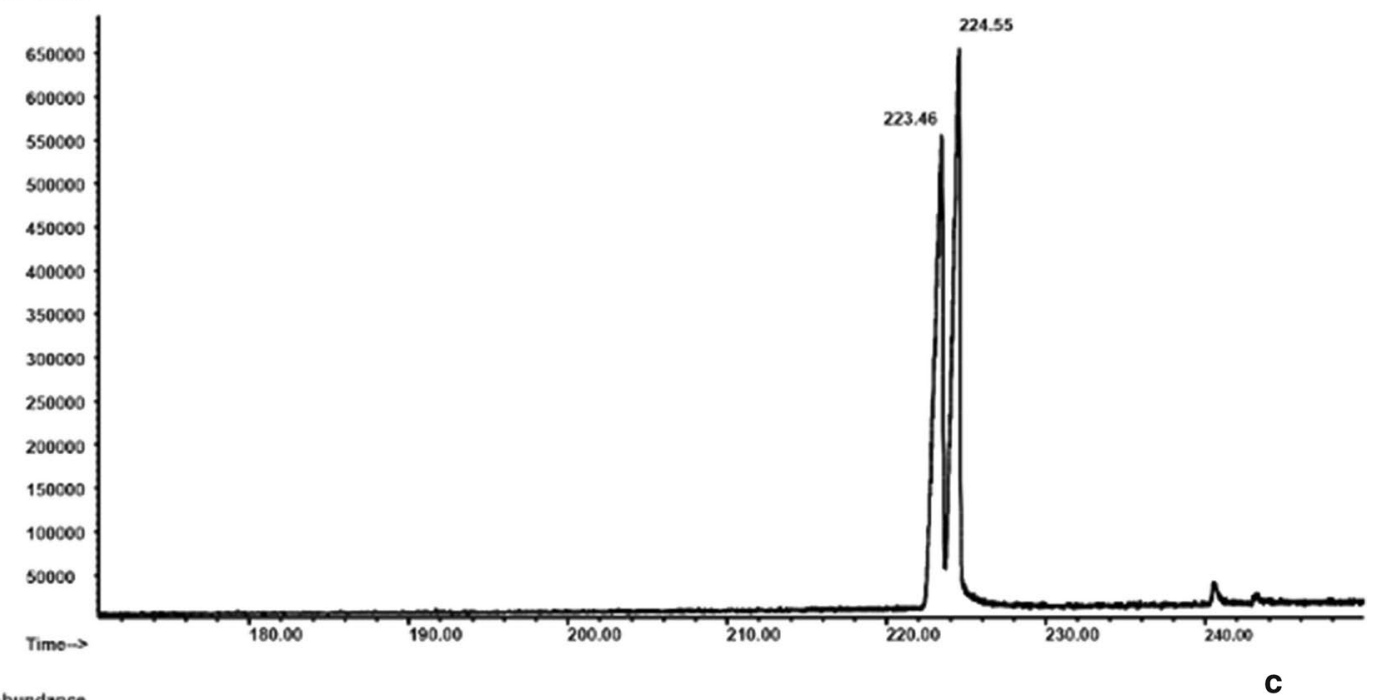

Abundance

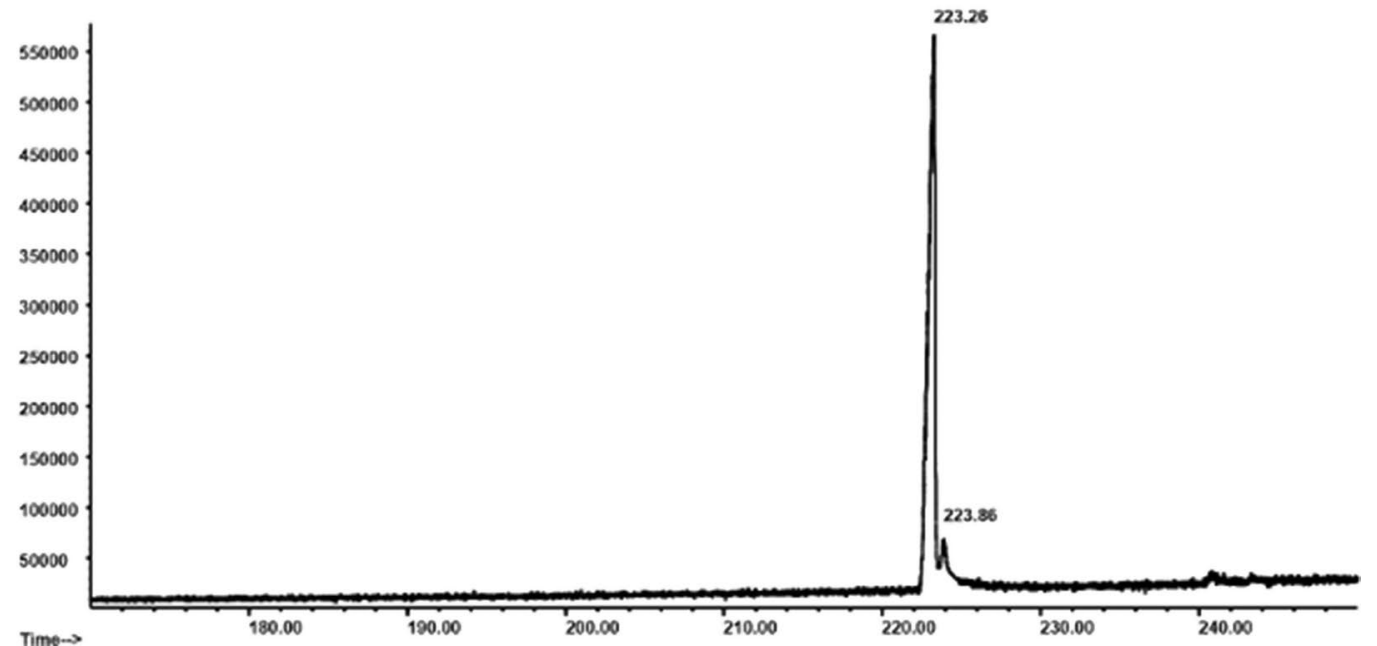

Fig. 1 Chiral GC/MS analyses of crude amides $\mathbf{2 7}$ and $\mathbf{2 8}$ : a (S)-2-(N-tert-butoxycarbonyl-amino)-N-phenylpropanamide (27); $\mathbf{b}$ a mixture of $\mathbf{2 7}$ and 28 (approx. 1:1); c (R)-2-(N-tert-butoxycarbonylamino)-N-phenylpropanamide (28) 


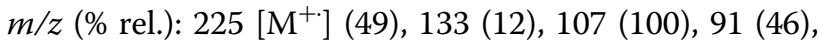
77 (9), 65 (12).

\section{N-propylbenzamide (10)}

Solid (91\%); $\mathrm{mp}=83-85{ }^{\circ} \mathrm{C} ; \mathrm{Rf}=0.64 ;{ }^{1} \mathrm{H}$ NMR (300 MHz, $\left.\mathrm{CDCl}_{3}\right) \delta: 7.82-7.69(\mathrm{~m}, 2 \mathrm{H}), 7.52-7.27(\mathrm{~m}$, $3 \mathrm{H}), 6.60\left(\mathrm{~s}_{\text {broad }}, 1 \mathrm{H}\right), 3.42-3.31(\mathrm{~m}, 2 \mathrm{H}), 1.70-1.51(\mathrm{~m}$, $2 \mathrm{H}), 0.93(\mathrm{t}, \mathrm{J}=7.4 \mathrm{~Hz}, 3 \mathrm{H}) ;{ }^{13} \mathrm{C}-\mathrm{NMR}\left(75 \mathrm{MHz}, \mathrm{CDCl}_{3}\right)$ $\delta: 167.6,134.8,131.1,128.4,126.8,41.7,22.8,11.3 ; \mathrm{GC} /$ MS (EI) $m / z$ (\% rel.): $163\left[\mathrm{M}^{+\cdot}\right]$ (28), 134 (7), 105 (100), 77 (30).

\section{4-nitro-N-propylbenzamide (11)}

Solid (92\%); $\mathrm{mp}=102-104{ }^{\circ} \mathrm{C} ; \mathrm{Rf}=0.50 ;{ }^{1} \mathrm{H}$ NMR $\left(300 \mathrm{MHz}, \mathrm{CDCl}_{3}\right) \delta: \delta: 8.21(\mathrm{~d}, \mathrm{~J}=8.8 \mathrm{~Hz}, 2 \mathrm{H}), 7.92$ $(\mathrm{d}, \mathrm{J}=8.8 \mathrm{~Hz}, 2 \mathrm{H}), 6.74\left(\mathrm{~s}_{\text {broad }}, 1 \mathrm{H}\right), 3.44-3.34(\mathrm{~m}, 2 \mathrm{H})$, 1.74-1.53 (m, 2H), $0.95(\mathrm{t}, \mathrm{J}=7.4 \mathrm{~Hz}, 3 \mathrm{H}) ;{ }^{13} \mathrm{C}-\mathrm{NMR}$ $\left(75 \mathrm{MHz}, \mathrm{CDCl}_{3}\right) \delta: 165.6,149.5,140.5,127.6,123.5$, 41.96, 22.6, 11.3; GC/MS (EI) $m / z$ (\% rel.): 208 [ $\left.\mathrm{M}^{+\cdot}\right]$ (21), 193 (12), 179 (12), 150 (100), 104 (23), 76 (15).

\section{4-methoxy-N-propylbenzamide (12)}

Solid (78\%); $\mathrm{mp}=58-60{ }^{\circ} \mathrm{C}$; $\mathrm{Rf}=0.54 ;{ }^{1} \mathrm{H}$ NMR $\left(300 \mathrm{MHz}, \mathrm{CDCl}_{3}\right) \delta: 7.74(\mathrm{~d}, \mathrm{~J}=8.8 \mathrm{~Hz}, 2 \mathrm{H}),, 6.87(\mathrm{~d}$, $\mathrm{J}=8.8 \mathrm{~Hz}, 2 \mathrm{H}), 6.45\left(\mathrm{~s}_{\text {broad }}, 1 \mathrm{H}\right), 3.81(\mathrm{~s}, 3 \mathrm{H}), 3.42-3.28$ (m, 2H), 1.70-150 (m, 2H), 0.94 (t, J = 7.4 Hz, 3H); ${ }^{13} \mathrm{C}-$ NMR $\left(75 \mathrm{MHz}, \mathrm{CDCl}_{3}\right)$ 8: 167.1, 162.0, 128.7, 127.1, 113.6, 55.4, 41.7, 22.9, 11.5; GC/MS (EI) $m / z$ (\% rel.): 193 [M+'] (19), 151 (10), 135 (100), 107 (5), 92 (10), 77 (12).

\section{4-chloro-N-propylbenzamide (13)}

Solid (96\%); $\mathrm{mp}=96-98{ }^{\circ} \mathrm{C} ; \mathrm{Rf}=0.58 ;{ }^{1} \mathrm{H}$ NMR $\left(300 \mathrm{MHz}, \mathrm{CDCl}_{3}\right) \delta: 7.75-7.65(\mathrm{~m}, 2 \mathrm{H}), 7.41-7.28(\mathrm{~m}$, $2 \mathrm{H}), 6.55\left(\mathrm{~s}_{\text {broad }}, 1 \mathrm{H}\right), 3.43-3.28(\mathrm{~m}, 2 \mathrm{H}), 1.70-1.50(\mathrm{~m}$, $2 \mathrm{H}), 0.94(\mathrm{t}, \mathrm{J}=7.4 \mathrm{~Hz}, 3 \mathrm{H}) ;{ }^{13} \mathrm{C}-\mathrm{NMR}\left(75 \mathrm{MHz}, \mathrm{CDCl}_{3}\right)$ $\delta: 166.5,137.4,133.2,128.6,128.3,41.8,22.7,11.3$; GC/ MS (EI) $m / z$ (\% rel.): $197\left[\mathrm{M}^{+\cdot}\right]$ (25), 168 (6), 139 (100), 111 (23), 75 (11).

\section{2-phenyl-N-propylacetamide (14)}

Solid (95\%); $\mathrm{mp}=66-69{ }^{\circ} \mathrm{C} ; \mathrm{Rf}=0.68 ;{ }^{1} \mathrm{H}$ NMR $\left(300 \mathrm{MHz}, \mathrm{CDCl}_{3}\right) \delta: 7.42-7.17(\mathrm{~m}, 5 \mathrm{H}), 5.65\left(\mathrm{~s}_{\text {broad }}, 1 \mathrm{H}\right)$, $3.55(\mathrm{~s}, 2 \mathrm{H}), 3.22-3.07(\mathrm{~m}, 2 \mathrm{H}), 1.58-1.31(\mathrm{~m}, 2 \mathrm{H}), 0.82$ $(\mathrm{t}, \mathrm{J}=7.4 \mathrm{~Hz}, 3 \mathrm{H}) ;{ }^{13} \mathrm{C}-\mathrm{NMR}\left(75 \mathrm{MHz}, \mathrm{CDCl}_{3}\right) \delta: 171.0$, 135.1, 129.4, 129.0, 127.3, 43.8, 41.3, 22.7, 11.2; GC/MS

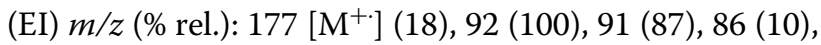
65 (13), 43 (23).

\section{N-propylcinnamamide (15)}

Solid (97\%); mp $=75-77{ }^{\circ} \mathrm{C}$; Rf $=0.71 ;{ }^{1} \mathrm{H}$ NMR $\left(300 \mathrm{MHz}, \mathrm{CDCl}_{3}\right) \delta: 7.62(\mathrm{~d}, \mathrm{~J}=15.6 \mathrm{~Hz}, 1 \mathrm{H}), 7.54-7.41$ (m, 2H), 7.38-7.25 (m, 3H), $6.50(\mathrm{~d}, \mathrm{~J}=15.6 \mathrm{~Hz}, 1 \mathrm{H})$, 6.34 (sbroad, $1 \mathrm{H}), 3.47-3.26(\mathrm{~m}, 2 \mathrm{H}), 1.71-1.49(\mathrm{~m}, 2 \mathrm{H})$, $0.94(\mathrm{t}, \mathrm{J}=7.4 \mathrm{~Hz}, 3 \mathrm{H}) ;{ }^{13} \mathrm{C}-\mathrm{NMR}\left(75 \mathrm{MHz}, \mathrm{CDCl}_{3}\right) \delta$ : 166.1, 140.5, 134.9, 128.7, 127.7, 127.7, 121.1, 41.4, 22.8, 11.4; GC/MS (EI) $m / z$ (\% rel.): 189 [M $\left.{ }^{+\cdot}\right]$ (27), 131 (100), 174 (5), 146 (24), 103 (40), 77 (24).

\section{N-propylpalmitamide (16)}

Solid (94\%), $\mathrm{mp}=74-76{ }^{\circ} \mathrm{C} ; \mathrm{Rf}=0.81 ;{ }^{1} \mathrm{H}$ NMR $\left(300 \mathrm{MHz}, \mathrm{CDCl}_{3}\right) \delta: 5.49\left(\mathrm{~s}_{\text {broad }}, 1 \mathrm{H}\right), 3.27-3.14(\mathrm{~m}, 2 \mathrm{H})$, 2.20-2.09 (m, 2H), 1.73-1.58 (m, 2H), 1.57-1.41 (m, $2 \mathrm{H}), 1.40-1.11(\mathrm{~m}, 24 \mathrm{H}), 0.98-0.78(\mathrm{~m}, 6 \mathrm{H}) ;{ }^{13} \mathrm{C}-\mathrm{NMR}$ (75 $\mathrm{MHz}, \mathrm{CDCl}_{3}$ ) $\delta: 173.1,41.2,37.0,31.9,29.7,29.6$, 29.5, 29.4, 29.3, 25.9, 22.9, 22.7, 14.1, 11.4; GC/MS (EI) $m / z$ (\% rel.): $297\left[\mathrm{M}^{+}\right.$] (3), 268 (3), 239 (3), 114 (24), 101 (100), 43 (14).

\section{$\mathrm{N}, \mathrm{N}$-diethylbenzamide (17)}

Viscous oil (64\%); $\mathrm{Rf}=0.75 ;{ }^{1} \mathrm{H}$ NMR $\left(300 \mathrm{MHz}, \mathrm{CDCl}_{3}\right)$ $\delta: 7.41-7.10(\mathrm{~m}, 5 \mathrm{H}), 3.43\left(\mathrm{~s}_{\text {broad }}, 2 \mathrm{H}\right), 3.14\left(\mathrm{~s}_{\text {broad }}, 2 \mathrm{H}\right)$, 1.27-0.89 (m, 6H); ${ }^{13} \mathrm{C}-\mathrm{NMR}\left(75 \mathrm{MHz}, \mathrm{CDCl}_{3}\right) \delta: 171.1$, 137.1, 128.9, 128.2, 126.1, 43.1, 39.1, 14.0, 12.7; GC/MS

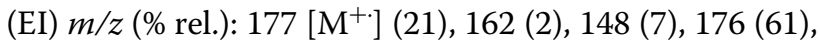
105 (100), 77 (27).

\section{$\mathrm{N}, \mathrm{N}$-diethyl-4-nitrobenzamide (18)}

Solid (80\%); $\mathrm{mp}=54-56{ }^{\circ} \mathrm{C} ; \mathrm{Rf}=0.73 ;{ }^{1} \mathrm{H}$ NMR $\left(300 \mathrm{MHz}, \mathrm{CDCl}_{3}\right) \delta: 8.26(\mathrm{~d}, \mathrm{~J}=8.8 \mathrm{~Hz}, 2 \mathrm{H}), 7.53(\mathrm{~d}$, $\mathrm{J}=8.8 \mathrm{~Hz}, 2 \mathrm{H}), 3.73-3.36(\mathrm{~m}, 2 \mathrm{H}), 3.34-3.01(\mathrm{~m}, 2 \mathrm{H})$, $1.25(\mathrm{t}, \mathrm{J}=6.9 \mathrm{~Hz}, 3 \mathrm{H}), 1.11(\mathrm{t}, \mathrm{J}=6.9 \mathrm{~Hz}, 3 \mathrm{H}) ;{ }^{13} \mathrm{C}-\mathrm{NMR}$ $\left(75 \mathrm{MHz}, \mathrm{CDCl}_{3}\right) \delta: 168.9,148.3,143.4,127.3,123.9,43.3$, 39.5, 14.2, 12.8; GC/MS (EI) $m / z$ (\% rel.): $222\left[\mathrm{M}^{+}\right]$(17), 221 (42), 205 (7), 175 (4), 150 (100), 120 (13), 104 (25), 92 (8), 76 (14).

\section{$\mathrm{N}, \mathrm{N}$-diethyl-4-methoxybenzamide (19)}

Oil (56\%); Rf $=0.65 ;{ }^{1} \mathrm{H}$ NMR $\left(300 \mathrm{MHz}, \mathrm{CDCl}_{3}\right) \delta: 7.22$ $(\mathrm{d}, \mathrm{J}=8.7 \mathrm{~Hz}, 2 \mathrm{H}), 6.77$ (d, J = 8.7 Hz, 2H), $3.68(\mathrm{~s}, 3 \mathrm{H}$, ), 3.29 ( $\left.\mathrm{s}_{\text {broad }}, 4 \mathrm{H}\right), 1.05$ ( $\left.\mathrm{s}_{\text {broad }}, 6 \mathrm{H}\right) ;{ }^{13} \mathrm{C}-\mathrm{NMR}(75 \mathrm{MHz}$,

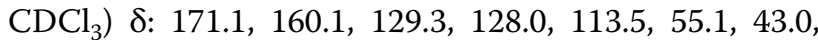

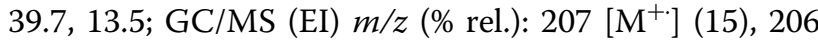
(34), 135 (100), 107 (4), 92 (11), 77 (9).

\section{4-chloro- $\mathrm{N}, \mathrm{N}$-diethylbenzamide (20)}

Oil (77\%); Rf $=0.65 ;{ }^{1} \mathrm{H}$ NMR (300 $\left.\mathrm{MHz}, \mathrm{CDCl}_{3}\right) \delta$ : 7.41-7.24 (m, $4 \mathrm{H}, \mathrm{ArH}), 3.50\left(\mathrm{~s}_{\text {broad }}, 2 \mathrm{H}\right), 3.22\left(\mathrm{~s}_{\text {broad }}, 2 \mathrm{H}\right)$, 1.31-0.98 (m, 6H); ${ }^{13} \mathrm{C}-\mathrm{NMR}\left(75 \mathrm{MHz}, \mathrm{CDCl}_{3}\right) \delta: 170.2$, 135.6, 135.1, 128.7, 127.8, 43.1, 39.1, 14.1, 12.7; GC/MS (EI) $m / z$ (\% rel.): $211\left[\mathrm{M}^{+\cdot}\right]$ (15), 210 (34), 139 (100), 111 (23), 75 (9).

\section{$\mathrm{N}, \mathrm{N}$-diethyl-2-phenylacetamide (21)}

Oil (85\%); Rf $=0.73 ;{ }^{1} \mathrm{H}$ NMR $\left(300 \mathrm{MHz}, \mathrm{CDCl}_{3}\right) \delta: 7.36-$ $7.15(\mathrm{~m}, 5 \mathrm{H}), 3.69(\mathrm{~s}, 2 \mathrm{H}), 3.38(\mathrm{q}, \mathrm{J}=7.1 \mathrm{~Hz}, 2 \mathrm{H}), 3.28(\mathrm{q}$, $\mathrm{J}=7.1 \mathrm{~Hz}, 2 \mathrm{H}), 1.16-1.02(\mathrm{~m}, 6 \mathrm{H}) ;{ }^{13} \mathrm{C}-\mathrm{NMR}(75 \mathrm{MHz}$, 
$\left.\mathrm{CDCl}_{3}\right) \delta: 170.2,135.5,128.7,128.6,126.6,42.4,40.9$, 40.1, 14.2, 12.9; GC/MS (EI) $m / z$ (\% rel.): $191\left[\mathrm{M}^{+\cdot}\right.$ ] (38), 118 (3), 100 (100), 91 (46), 72 (50).

\section{$\mathrm{N}, \mathrm{N}$-diethylcinnamamide (22)}

Solid (87) \%); $\mathrm{mp}=58-60{ }^{\circ} \mathrm{C} ; \mathrm{Rf}=0.73 ;{ }^{1} \mathrm{H}$ NMR $(300 \mathrm{MHz}, \mathrm{CDCl} 3) \delta: 7.55(\mathrm{~d}, \mathrm{~J}=15.4 \mathrm{~Hz}, 1 \mathrm{H}), 7.41-$ $7.27(\mathrm{~m}, 2 \mathrm{H}), 7.24-7.04(\mathrm{~m}, 3 \mathrm{H}), 6.68(\mathrm{~d}, \mathrm{~J}=15.4 \mathrm{~Hz}$, $1 \mathrm{H}), 3.42-3.15(\mathrm{~m}, 4 \mathrm{H}), 1.16-0.92(\mathrm{~m}, 6 \mathrm{H}) ;{ }^{13} \mathrm{C}-\mathrm{NMR}$ $\left(75 \mathrm{MHz}, \mathrm{CDCl}_{3}\right) \delta: 165.4,141.9,135.3,129.2,128.6$, 127.5, 117.7, 42.1, 40.9, 14.9, 13.0; GC/MS (EI) $\mathrm{m} / z$ (\% rel.): $203\left[\mathrm{M}^{+}\right]$(32), 188 (8), 131 (100), 126 (8), 103 (35), 77 (12).

\section{$\mathrm{N}, \mathrm{N}$-diethylpalmitamide (23)}

Oil (91) \%); Rf $=0.73 ;{ }^{1} \mathrm{H}$ NMR $\left(300 \mathrm{MHz}, \mathrm{CDCl}_{3}\right) \delta$ : 3.42-3.21 (m, 4H), 2.35-2.19 (m, 2H), 1.71-1.51 (m, 2H), 1.39-0.99 (m, 30H), $0.87(\mathrm{t}, \mathrm{J}=6.7,3 \mathrm{H}) ;{ }^{13} \mathrm{C}-\mathrm{NMR}$

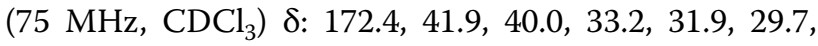
29.6, 29.5, 29.4, 25.5, 22.7, 14.4, 14.1, 13.1; GC/MS (EI)

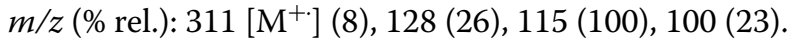

\section{N-phenylpivalamide (24)}

Solid (90\%); $\mathrm{mp}=133-135{ }^{\circ} \mathrm{C} ; \mathrm{Rf}=0.82 ;{ }^{1} \mathrm{H}$ NMR (300 MHz, $\left.\mathrm{CDCl}_{3}\right)$ 8: 7.57-7.50 (m, 2H), $7.43\left(\mathrm{~s}_{\text {broad }}\right.$, $1 \mathrm{H})$, 7.36-7.25 (m, 2H), 7.14-7.04 (m, 1H), $1.32(\mathrm{~s}, 9 \mathrm{H})$; ${ }^{13} \mathrm{C}-\mathrm{NMR}\left(75 \mathrm{MHz}, \mathrm{CDCl}_{3}\right) \delta: 176.6,138.0,128.9,124.2$, 120.0, 39.6, 27.6; GC/MS (EI) $m / z$ (\% rel.): 177 [M $\left.\mathrm{M}^{+}\right]$(90), 120 (7), 93 (100), 77 (12), 57 (95).

\section{N-propylpivalamide (25)}

Oil (75\%); Rf $=0.84 ;{ }^{1} \mathrm{H}$ NMR $\left(300 \mathrm{MHz}, \mathrm{CDCl}_{3}\right) \delta: 5.73$ (s, $1 \mathrm{H}), 3.23-3.11(\mathrm{~m}, 2 \mathrm{H}), 1.58-1.40(\mathrm{~m}, 2 \mathrm{H}), 1.16(\mathrm{~s}$, 9H), $0.88(\mathrm{t}, \mathrm{J}=7.4 \mathrm{~Hz}, 3 \mathrm{H}) ;{ }^{13} \mathrm{C}-\mathrm{NMR}\left(75 \mathrm{MHz}, \mathrm{CDCl}_{3}\right)$ $\delta: 178.4,41.2,38.6,27.6,22.8,11.3$; GC/MS (EI) $\mathrm{m} / z$ (\% rel.): $143\left[\mathrm{M}^{+\cdot}\right]$ (54), 128 (19), 114 (7), 100 (14), 86 (41), 85 (26), 57 (100), 43 (59).

\section{$\mathrm{N}, \mathrm{N}$-diethylpivalamide (26)}

oil (9\%); Rf $=0.65 ;{ }^{1} \mathrm{H}$ NMR $\left(300 \mathrm{MHz}, \mathrm{CDCl}_{3}\right) \delta: 3.48-$ $3.32(\mathrm{~m}, 4 \mathrm{H}), 1.29-1.18(\mathrm{~m}, 15 \mathrm{H}) ; \mathrm{GC} / \mathrm{MS}(\mathrm{EI}) \mathrm{m} / z(\%$ rel.): 157 [M $\left.{ }^{+\cdot}\right]$ (25), 142 (7); 100 (100), 72 (62), 57 (53).

\section{(S)-2-(N-tert-Butoxycarbonylamino)-N-phenylpropanamide} (27)

Oil (88\%); Rf = 0.80; ${ }^{1} \mathrm{H}$ NMR (300 MHz, $\left.\mathrm{CDCl}_{3}\right) \delta: 8.86$ $\left(\mathrm{s}_{\text {broad }}, 1 \mathrm{H}\right), 7.58-7.45(\mathrm{~m}, 2 \mathrm{H}), 7.36-7.19(\mathrm{~m}, 2 \mathrm{H}), 7.13-$ $7.01(\mathrm{~m}, 1 \mathrm{H}), 5.50(\mathrm{~d}, \mathrm{~J}=7.5 \mathrm{~Hz}, 1 \mathrm{H}), 4.53-4.31(\mathrm{~m}, 1 \mathrm{H})$, $1.48-1.38(\mathrm{~m}, 12 \mathrm{H}) ;{ }^{13} \mathrm{C}-\mathrm{NMR}\left(75 \mathrm{MHz}, \mathrm{CDCl}_{3}\right) \delta: 171.2$, $155.9,137.9,128.9,124.2,119.9,80.4,50.4,28.3,17.8$; GC/MS (EI) $m / z$ (\% rel.): $264\left[\mathrm{M}^{+\cdot}\right]$ (17), 208 (25), 191 (29), 144 (18), 120 (28), 93 (100), 77 (25), 57 (87).
(R)-2-(N-tert-Butoxycarbonylamino)-N-phenylpropanamide

(28)

Oil (87\%); Rf $=0.80 ;{ }^{1} \mathrm{H}$ NMR (300 MHz, $\left.\mathrm{CDCl}_{3}\right) \delta: 8.69$ ( $\left.\mathrm{s}_{\text {broad }}, 1 \mathrm{H}\right), 7.61-7.42(\mathrm{~m}, 2 \mathrm{H}), 7.33-7.21(\mathrm{~m}, 2 \mathrm{H}), 7.11-$ $7.02(\mathrm{~m}, 1 \mathrm{H}), 5.31(\mathrm{~d}, \mathrm{~J}=8.0 \mathrm{~Hz}, 1 \mathrm{H}), 4.49-4.27(\mathrm{~m}, 1 \mathrm{H})$, $1.51-1.38(\mathrm{~m}, 12 \mathrm{H}) ;{ }^{13} \mathrm{C}-\mathrm{NMR}\left(75 \mathrm{MHz}, \mathrm{CDCl}_{3}\right) \delta: 171.1$, 156.1, 137.8, 128.9, 124.2, 119.9, 80.7, 51.7, 28.3, 17.5; GC/MS (EI) $m / z$ (\% rel.): $264\left[\mathrm{M}^{+\cdot}\right]$ (17), 208 (24), 191 (28), 144 (18), 120 (28), 93 (100), (77 (25), 57 (92).

\section{Additional files}

Additional file 1. Supporting informations.

\section{Authors' contributions}

AL designed research and analyzed data; JB performed research; ELB and AC did the spectral analyses, MG participated in writing and editing results, and AL proposed the subject and approved the final manuscript. All authors read and approved the final manuscript.

\section{Competing interests}

The authors declare that they have no competing interests.

\section{Consent for publication}

Not applicable.

Ethics approval and consent to participate Not applicable.

\section{Publisher's Note}

Springer Nature remains neutral with regard to jurisdictional claims in published maps and institutional affiliations.

Received: 19 July 2017 Accepted: 5 September 2017 Published online: 15 September 2017

\section{References}

1. Carey JS, Laffan D, Thomson C, Williams MT (2006) Analysis of the reactions used for the preparation of drug candidate molecules. Org Biomol Chem 4:2337-2347

2. Yu X, Sun D (2013) Macrocyclic drugs and synthetic methodologies toward macrocycles. Molecules 18:6230-6268

3. Roughley SD, Jordan AM (2011) The medicinal chemist's toolbox: an analysis of reactions used in the pursuit of drug candidates. J Med Chem 54:3451-3479

4. Deming TJ (2002) Methodologies for preparation of synthetic block copolypeptides: materials with future promise in drug delivery. Adv Drug Deliver Rev 54:1145-1155

5. Montalbetti CAGN, Falque V (2005) Amide bond formation and peptide coupling. Tetrahedron 61:10827-10852

6. Leggio A, Di Gioia ML, Perri F, Liguori A (2007) N-Nosyl-a-amino acids in the solution phase peptide synthesis. Tetrahedron 63:8164-8173

7. Belsito EL, Di Gioia ML, Greco A, Leggio A, Liguori A, Perri F, Siciliano C, Viscomi MC (2007) N-Methyl-N-Nosyl- $\beta^{3}$-amino Acids. J Org Chem $72: 4798-4802$

8. Di Gioia ML, Leggio A, Liguori A, Perri F, Siciliano C, Viscomi MC (2010) Preparation of N-Fmoc-N-methyl-a-amino acids and N-nosyl-N-methyl-aamino acids. Amino Acids 38:133-143

9. Goodreid JD, Duspara PA, Bosch C, Batey RA (2014) Amidation reactions from the direct coupling of metal carboxylate salts with amines. J Org Chem 79:943-954 
10. Dunetz JR, Magano J, Weisenburger GA (2016) Large-scale applications of amide coupling reagents for the synthesis of pharmaceuticals. Org Process Res Dev 20:140-177

11. Valeur E, Bradley M (2009) Amide bond formation: beyond the myth of coupling reagents. Chem Soc Rev 38:606-631

12. Leggio A, Belsito EL, De Luca G, Di Gioia ML, Leotta V, Romio E, Siciliano C, Liquori A (2016) One-pot synthesis of amides from carboxylic acids activated using thionyl chloride. RSC Adv 6:34468-34475

13. El-Faham A, Albericio F (2011) Peptide coupling reagents, more than a letter soup. Chem Rev 111:6557-6602

14. Lundberg H, Tinnis F, Selander N, Adolfsson H (2014) Catalytic amide formation from non-activated carboxylic acids and amines. Chem Soc Rev 43:2714-2742

15. Pattabiraman VR, Bode JW (2011) Rethinking amide bond synthesis. Nature 480:471-479

16. Charville $H$, Jackson D, Hodges $G$, Whiting A (2010) The thermal and boron-catalysed direct amide formation reactions: mechanistically understudied yet important processes. Chem Commun 46:1813-1823

17. Allen CL, Chhatwal AR, Williams JMJ (2012) Direct amide formation from unactivated carboxylic acids and amines. Chem Commun 48:666-668

18. Wilson JD, Weingarten H (1970) Titanium tetrachloride promoted conversion of carboxylic acids to carboxamides. Can J Chem 48:983-986

19. Allen CL, Williams JMJ (2011) Metal-catalysed approaches to amide bond formation. Chem Soc Rev 40:3405-3415

20. Ishihara K, Ohara S, Yamamoto H (1996) 3,4,5-Trifluorobenzeneboronic acid as an extremely active amidation catalyst. J Org Chem 61:4196-4197

21. Ishihara K, Ohara S, Yamamoto H (2000) Direct polycondensation of carboxylic acids and amines catalyzed by 3,4,5-trifluorophenylboronic acid. Macromolecules 33:3511-3513

22. Liu S, Yang Y, Liu X, Ferdousi FK, Batsanov AS, Whiting A (2013) Direct amidation of amino acid derivatives catalyzed by arylboronic acids: applications in dipeptide synthesis. Eur J Org Chem 25:5692-5700

23. Lanigan RM, Starkov P, Sheppard TD (2013) Direct synthesis of amides from carboxylic acids and amines using $\mathrm{B}\left(\mathrm{OCH}_{2} \mathrm{CF}_{3}\right)_{3}$.J Org Chem 78:4512-4523

24. Huang W, Sha WB (2013) Direct amide formation from N-arylglycine ethyl esters and carboxylic acids catalysed by phenylboronic acid. J Chem Res 37:460-463

25. Werdehausen A, Weiss H (1972) Preparation of carboxylic acid amides Patent Application Pub. No.: DE2110060; Pub. Date: Sep. 07, 1972

26. Nordahl A, Carlson R (1988) Carboxamides from carboxylic acids by lewis acid catalysis. use of principal properties for exploring different reaction conditions. Acta Chem Scand B 42:28-34

27. Shteinberg LY, Kondratov SA, Shein SM (1988) Metal-complex catalysis in acylation of aniline by substituted benzoic acids. Zh Org Khim 24:1968-1972
28. Shteinberg LY, Kondratov SA, Shein SM (1989) Catalysis by tetrabutoxytitanium in the reaction of substituted anilines with benzoic acid. Zh Org Khim 25:1945-1949

29. Lundberg H, Tinnis F, Adolfsson H (2012) Titanium(IV) isopropoxide as an efficient catalyst for direct amidation of nonactivated carboxylic acids. Synlett 23:2201-2204

30. Lundberg $\mathrm{H}$, Tinnis F, Adolfsson $\mathrm{H}$ (2012) Direct amide coupling of non-activated carboxylic acids and amines catalysed by Zirconium(IV) Chloride. Chem Eur J 18:3822-3826

31. Tinnis F, Lundberg H, Kivijärvi T, Adolfsson H (2015) Zirconium (IV) chloride catalyzed amide formation from carboxylic acid and amine: (S)-tert-Butyl 2-(Benzylcarbamoyl)pyrrolidine-1-carboxylate. Org Synth 92:227-236

32. Lundberg $\mathrm{H}$, Adolfsson $\mathrm{H}$ (2015) Hafnium-Catalyzed direct amide formation at room temperature. ACS Catal 5:3271-3277

33. Leggio A, Belsito EL, Gallo S, Liguori A (2017) One-pot conversion of aldehydes to nitriles mediated by $\mathrm{TiCl}_{4}$. Tetrahedron Lett 58:1512-1514

34. Di Gioia ML, Leggio A, Le Pera A, Liguori A, Siciliano C (2004) Highly stereoselective conversion of aryl peptidyl ketones into the corresponding peptide alcohols. Eur J Org Chem 2004(3):463-467

35. Di Gioia ML, Leggio A, Le Pera A, Liguori A, Pitrelli AF, Siciliano C (2005) A convenient method for the stereoselective conversion of aryl peptidyl ketones into the corresponding aryl aminomethin derivatives, a novel class of modified peptides. Protein Pept Lett 12:357-362

36. Leggio A, Belsito EL, Di Gioia ML, Leotta V, Romio E, Siciliano C, Liguori A (2015) Reduction of amide carbonyl group and formation of modified amino acids and dipeptides. Tetrahedron Lett 56:2062-2066

37. Di Gioia ML, Leggio A, Le Pera A, Liguori A, Perri F, Siciliano C (2004) Alternative and chemoselective deprotection of the alpha-amino and carboxy functions of N-Fmoc-amino acid and N-Fmoc-dipeptide methyl esters by modulation of the molar ratio in the $\mathrm{AlCl} 3 / \mathrm{N}, \mathrm{N}$-dimethylaniline reagent system. Eur J Org Chem 21:4437-4441

38. Di Gioia ML, Leggio A, Guarino IF, Leotta V, Romio E, Liguori A (2015) A simple synthesis of anilines by $\mathrm{LiAlH}_{4} / \mathrm{TiCl}_{4}$ reduction of aromatic nitro compounds. Tetrahedron Lett 56:5341-5344

39. Shi M, Jiang J-K, Feng Y-S (2000) Titanium(IV) chloride and the aminepromoted Baylis-Hillman reaction. Org Lett 16:2397-2400

40. Periasamy M (2002) New synthetic methods using the $\mathrm{TiCl}_{4}-\mathrm{NR}_{3}$ reagent system. Arkivok 6:151-166

41. Weissman SA, Zewge D (2005) Recent advances in ether dealkylation. Tetrahedron 61:7833-7863

42. Rajakumar P, Murali V (2003) $\mathrm{TiCl}$, dioxane-A facile and efficient system for De-O-Benzylation, De-O-Allylation, and De-O-Xylylation of phenolic ethers. Synth Commun 33:3891-3896

\section{Submit your manuscript to a SpringerOpen ${ }^{\circ}$ journal and benefit from:}

- Convenient online submission

- Rigorous peer review

- Open access: articles freely available online

- High visibility within the field

Retaining the copyright to your article

Submit your next manuscript at springeropen.com 